\title{
OPPORTUNITIES AND BENEFITS IMPLEMENTATION BUSINESS INTELLIGENCE APPLICATION ON HEALTH CENTER
}

\author{
Hady Pranoto \\ Computer Science Department, School of Computer Science, Binus University \\ Jl. K.H. Syahdan No. 9, Palmerah, Jakarta Barat 11480 \\ hadypranoto@gmail.com
}

\begin{abstract}
The health center has the task of providing health services to the community, to be able to win the competition among the existing health centers; a health center should have a good operating system, $a$ computerized operating system to improve services in the field of administration. However, providing a computerized system is not enough, many other health centers or competitors also use a computerized system. Unfortunately, health centers in Indonesia have not yet implemented business intelligence application. There are many public and private health centers do not apply automated operational system. A study of the literature is conducted to find evidence of the application of BI, and any sector of the BI can be applied. Many sectors in health services where BI can be applied to improve the productivity quality of service and competitiveness in this era of globalization.
\end{abstract}

Keywords: business intelligence, health center, decision support system

\begin{abstract}
ABSTRAK
Pusat kesehatan mempunyai tugas menyediakan layanan kesehatan yang baik kepada masyarakat, untuk dapat menang persaingan diantara pusat kesehatan yang ada, sebuah pusat kesehatan harus mempunyai sistem operasional yang baik, sebuah sistem operasional yang terkomputerisasi untuk meningkatkan layanan dalam bidang adminstrasi. Tapi menenyediakan sistem terkomputerisasi saja tidak cukup, banyak pusat kesehatan pesaing juga mengunakan sistem yang terkomputerisasi. Sayang sekali pusat kesehatan di Indonesia, belum memiliki aplikasi inteligen bisnis. Operasional yang terotomasi kedalam sistem saja masih banyak pusat kesehatan pemerintah maupun swasta belum menerapkannya. Penulis melakukan study literatur untuk mencari bukti-bukti penerapan BI, dan melakukan kajian disektor mana saja BI dapat diterapkan. Banyak sektor dalam kesehatan di mana BI dapat diterapkan untuk meningkatkan produktivitas, kualitas layanan dan daya saing di era global ini.
\end{abstract}

Kata kunci: business intelligence, pusat kesehatan, decision support system 


\section{INTRODUCTION}

As a developing country, Indonesia will certainly pay attention to the health of the people and when a country has healthy people, the country will quickly become an advanced country. That is why every country has an organization that handles health matter, whether it's called a hospital, clinic, or community health center. For ease on writing, the following term will be referred to a health center. The main objectivity of a health center is making people healthy. To achieve a healthy society, a health center must provide health care services in accordance with what the community needs.

Health center has a challenge to meet the government regulations. The regulation made to ensure that the public will get a good standard of health services from the health center and health center is forced to evaluate and analyze business processes and practices of theirs. The standard set by Indonesia government forced health center to provide appropriate health care and relevant treatment that eliminates the patient's complications, collects data about the patient illness, gives treatments and results of these treatments (Nelson \& Sen, 2014), this data will be useful in the future medical care. A health center needs to make some improvements to the quality of service. One way to improve the quality of service is automating their operations and their operations are structured. To win against the competition, health centers need to have a system that can meet the needs of management in taking strategic decisions. Superior strategic decisions need to be taken in order to win the competition. A decision that could predict an event that will take place and will strengthen the ability to compete with competitors, or an intelligent system that is capable to operate efficiently will streamline the costs. Only few of health center use information they have for this.

However, the health center in Indonesia has not implemented automated operational system, especially BI applications. Then how health centers in Indonesia can compete? If automated operational system alone is not applied. This research would do a literature study on which a BI application can improve the quality of service and competition. Which sectors can be explored to improve services and competition?

This research aims to provide literature evidence for implementation of BI application in Health Center to encourage the implementation of Business Intelligent System as part of the organization in order to remind them about performance and competitiveness.

\section{Literature Review}

Like any others industry, a private health center or government health center also faces the challenge to increase revenue earning, reduce cost, increase utility of facility and improve quality of service. It is required a good governance in running the health center to increase effectively and optimally without reducing the quality of the services provided. To achieve this objective, it requires a good operational system. Business competition among health centers also leads a health center to have strategic goals to win the business competition. These strategic goals can only be achieved if the top management of health centers have adequate information for strategic decision making.

\section{Operational System}

Operational system is often also called the automated system/Online Transaction Processing (OLTP) system; this is a system that is widely used as a tool in their daily work. The original purpose of this system is to make sure the running of main daily business operations (Making the Wheels of Business Turn) (Ponniah, 2010). Meanwhile, according to Williams (2007), Operational System is a system that is designed and optimized to capture an individual transaction of business (usually current year) that appears. The system also updates the events of necessary business to run a business. Report needed but it is the second option when building this type of a system (Williams \& Williams, 2007). 


\section{Operational System versus Management Information System}

A Management Information System (MIS) of a system can provide strategic information that will be used by top-level management to make a strategic decision making. Management Information System (MIS) is known as a Decision Support System (DSS). It is a system of data processing to produce information that is used for information retrieval (Inmon, 2005). An Information System is used to see how the business is run (Watch how the Wheels of Business Turn). To see how a business process running, MIS will usually use reports and Online Analytical Processing (OLAP). To distinct between operational systems, the difference between Operational System and Information System can be seen on the table below:

Table 1 the Difference Operational System and Management Information System

\begin{tabular}{lll}
\hline & Operational System & \multicolumn{1}{c}{ Information System } \\
\hline Data content & Current & Archived data, derived, and summarized. \\
Data Structure & Optimized for transaction. & Optimized for complex query for analysis. \\
Access Frequency & High & Low to medium \\
Access Type & Read, Update and Delete & Read \\
Usage & Can predictable, routine, and repetition & Ad hoc, random and heuristic \\
Respond & Less than one second & One second or more, may be several minute. \\
\hline
\end{tabular}

\section{Business Intelligence System}

When looking for difference benefits between a Business Intelligence System and MIS/DSS, it is known that two systems have the same purposes. They are used by senior management as resources and strategic information in making a strategic decision. The difference Business Intelligence with the MIS/DSS is treatment level of the data, how to strategic information generated, usually in the MIS/DSS strategic information generated using reports, OLAP queries. In a Business Intelligence System, strategic information generated will go through a process of data mining and mathematical modeling.

\section{Data Mining}

Definition of data mining in information technology today is something to do on the data to get knowledge (Ponniah, 2010). It is known that the application of data mining is widely used in marketing, sales, credit analysis and detection of crime. Marketing application used to observe customer behavior and the effect of promotion on the sales application to view the sales performance, purchasing trends, prediction of sales improvement and credit analysis application, which is used to assessment credit risk when a customer want apply for credit. Data mining also begins to use developing Business Intelligent applications in the production management, inventory applications, and application of human resource department. Even now, it is used in predicting the value of the stock price on stock market, predicting bankruptcy a company and also in a medical center. A data mining process is sourced from a data warehouse, because if it is done directly into the System Operations/OLTP, the data mining process will overload the operational system.

There are seven basic tasks of data mining that can be identified (Vercellis, 2009): (1) Characterization and discrimination; When a categorical attribute can be found, before forming a classification model, it is necessary to explore the two functions of analysis, the first is aimed in comparing the characteristics of the distribution of value among the attribute, whether the attribute has the same class and on the other hand is to detect differences among attributes, by comparing the characteristics between distributions that the difference can be seen in class attribute. (2) 
Classification; classifying groups of attributes that are known and represented by the data set, for example classification phone users based on age, frequency of usage, etc. (3) Regression; Unlike classification used to discrete targets, regression is used when the target variable has continuous data. The goal is to predict the value of the target variable. (4) Time series; sometimes the target attribute evolves from one time to time, and it has an objective to find pattern on variable between time axis/series. (5) Association rules; otherwise known association with the grouping based on affinity, is to identify something interesting between groups of data sets. (6) Clustering: The term of cluster refers to homogeneous subgroups of a population. Clustering technique aims to classify heterogeneous population into small homogeneous groups to be used as research material, these small groups typically have the same characteristics and by comparing clusters with each other a grouping of information from them can be drawn. In contrast to the classification in which the data is labeled, the clustering grouping data is not labeled. (7) Description and visualization: This is the final step of data mining, information obtained from previously represented data mining processes need to be read and used. These representations can be formed with the graph, label and color.

\section{Association}

When a method has found a relationship between variables, it is necessary to find an algorithm in pattern. To find a relationship pattern, the following techniques can be used: (1) Association discovery; finding patterns among the items that the closeness with another item. The algorithm is trying to find combinations of the existence of an item that is encouraged to be close to other items. When visiting a supermarket an item can be found close with the other products, some products are always purchased together. (2) Sequential Pattern Discovery; As the name implies, this algorithm trying to find a pattern when a group items to follow a group of other sets of specific, time elements play a major role in this pattern. When a couple of records are taken to be analyzed, the date and time of the data items need to be picked to find sequential patterns. (3) Similar Time Sequence Discovery: This technique depends on the availability of information chronologically. In the technical before, the results show a sequence of events at a time. In this technique, the group wants to find a pattern of sequential events with another group of sequential events that are almost similar. For example, search for a product price movement of goods.

\section{Understanding of the Relationship and Pattern}

Relationship is for example, in a supermarket sometimes there are different types of goods placed close together, such as bread, milk and cheese. Is this a coincidence? If it is observed carefully, some patterns can be seen when someone buys a bread, sometimes he/she also buys milk, or sometimes buy cheese, the supermarket chain could have used a data mining process to see the pattern of relationships that every customer who buys bread also buy milk and cheese.

Pattern is for example, knowledge of the pattern is often used by credit card companies to increase credit card limit temporary. By using a data mining, companies have observe that there are shopping habits of customers' credit card at the end of the year, or the feast of harvest. By looking at the pattern, the credit card companies will raise the customer credit card limit temporarily, with the expectation that the credit card holder will be more likely to use credit cards, buy something and that means increasing revenue for the company through bank interest when saving more. Usually, credit card companies will not directly pay credit card merchant when customers buy items, credit card companies take advantage from the time payment delay between merchant and bank.

Some aspects of the analysis of data mining are: (1) Association; legal and powerful methods used in data mining to discover how a variable relates to other variables among them. (2) Outlier Analysis; this method focuses on the events that are not uncommon event among these variables. (3) Predictive Analysis; The most widely used method in data mining, the method of using previous data to obtain a prediction of events that will happen in the future. 
The main techniques in data mining are: (1) Cluster Detection; cluster means a group formed and identified. For example, it is time to wash clothes, usually the clothes are divided into groups of clothing colors, white-color, dark-colored, light-colored, clothing prints, and dry clean cloth. It has five clusters, and the cluster characteristic takes different actions. (2) Memory Based Reasoning (MBR); a technique that uses the similarity of data on the current situation with the situation ever. (3) Neural Network; this method of trying to find a pattern with neural methods such as the human brain, the algorithm is trained with the training data and it applies the data using the actual data to find common patterns for classification and prediction.

\section{METHOD}

In this research, the method used is qualitative methods. Some of the literature is reviewed and compared, opinions and judgments are expressed on the writings. Literature is analyzed and explored to get the best solution from a variety of way that has been done before. Concept is sensitized form many reviewed journals and conclusion is made for the best of it.

\section{RESULTS AND DISCUSION}

Health Center, Private ownership or State ownership should have information system for operational and management to administrating daily operation, and management is, with this automated system health center can perform quickly and give better performance to give satisfaction to the customer. But if the health center just giving this, they will lose in competition between health centers. Health Center must have something new to winning the competition. To win a competition many factor must considered by the health center management. It wouldn't discuss that all factor. This article will only discuss one factor: information. If someone wants to rule the world, he/she has to control the information. It is also in the business world, if someone wants to win the competition, he/she has to master the information. The information can be from internal or from external data or both of them. Data from internal is raw data, to get information or knowledge some process are needed, the process called data mining. With data mining, data form operational system will transform to information or knowledge. The information and knowledge can be used by management to make a strategic decision. But one must be remembered, the quality of information or knowledge depends on the quality and quantity of data obtained from the operational data. Look at that fact automatically level of automation in the health center will affect the amount and quality of information obtained, a Business Intelligence application not is able to work without adequate data.

Health center, good health information needs to be seen as an asset. To fully appreciate the value of information, Health Center needs to recognize the importance of a clear vision for information management and how it can support the overall transformation of Health Center (Hanson, 2011). Before being able to utilize Business Intelligence in the organization, a health center should first build an operational system and management information system and then build business intelligence at health center

\section{Building an Operational System and Management Information System}

Operational System is built in purpose is to ascertain how a business process running better, faster and more accurate. In order to build an operating system in a health center, what a health center needs is the first thing to be understood. Management information system provides information to the management to take tactical decisions. For that, the needs of a health center have to be analyzed. 
According to Mettler in his journal, the needs of a health center are as follows (Mettler \& Vimarlund, 2009):

- Information

o Patients

o Medications

o Financial

o Employees

- $\quad$ Medical Process

o Diagnosis and therapy / Electronic Medical Record ( EMR )

o Nurses Care

o Research and Teaching

- $\quad$ Business Process

o Financial Accounting

o Monitoring and Controling System

o Organizational Structure

o Compliance and Risk Management

o Scheduling

- $\quad$ Support Process

o Human Resource

o Logistics and Supply

o Communication

According to (Stegwee \& Teitink, 2002) information system was built in health center can give information about: (1) The number of procedures performed by specialists. (2) The percentage of use of the room and the bed. (3) The average length of hospitalization. (4) The number of first meeting prospective patients with specialist. (5) Total cost of caring process.

\section{Building a Business Intelligence at Health Center}

Once the operational and tactical needs have been met by operational systems and information systems, and they running well, then the senior management of the health center can capitalize on the data from the system to build its Business Intelligence System. BI system will process and utilizing data from operational system and management information, and exploit them to product a new information or knowledge. The new information and knowledge from BI system, can use as a strategic information that can used as consideration in strategic decision or formulate a future strategy that can improve the competitive power of a health center.

As an example use of the data held from operational system and MIS that can be exploited in BI application: (1) Address the patient's, an demographic information of patient and data Diagnosis and therapy/Electronic Medical Record (EMR), can be used to determine whether a region being affected by a disease epidemic, when many outpatient or inpatient come from the same area and with the same disease, with clustering technique on data mining it can be predicted if that the region is going on epidemic of a disease, for example such as dengue fever. By knowing pattern, this health center can launch a health care program to tackle the epidemic stricken on that area or prepare the drugs cure the disease. With this action, health center will achieve proud achievement. (2) Medical decision support for the doctor, for example: analysis of digitized of skin lesions to diagnose melanoma, predicting the presence of brain neoplasm with resonance spectroscopy and analysis digital image of tissue section to indentify and quantify senile plague, for Alzheimer's disease. With classification technique on data mining, it is possible to do that. (3) Decision tree and classification on data mining can exploit the Medicine Information and Electronic Medical Records, can use by BI 
application, to produce information about a medicine, can cure a disease or not, when a drug can't cure a disease, the purchase of the drug can be stopped, in this way a health center can save expenses from drugs unused, expired or should be discarded. With this information they can make decision to applied a treatment to patient or not. And with combining with time series health center can predict when they must added the drug. (3) At Cardinal Health BI implemented to helps identify patients at risk for disease. One of the greatest features of business intelligence, affecting health management, is that it has the ability to identify patients at risk for disease (Ashrafi, Kelleher, \& Kuilboer, 2014). (4) At Sahlgrenska University Hospital in Gothenburg, Sweden, business intelligence was used to provide doctors with a simple, easy and fast way to sift through test results and evaluate whether a patient recovering from brain surgery had meningitis and how it should be treated (Sabherwal \& Becerra Fernandez, 2011). (5) Electronic Medical Record data alone can be used by BI to determine a successful treatment methods to cure patients or not, if there is a method of treatment is ineffective or even cause side effects/complication, would that kind of treatment is stopped, let a health center benefit from a number of patients who come and can heal, not from long of duration patients hospitalization. (6) Logistics and Supply data can used by Intelligent Business to determine when an item of goods must be ordered back, so as not to run out stock, can be fatal if an patient illness not cure because the drug out of stock. (7) Scheduling data and patient data can also be used to determine when a specialist or doctor should be in a hospital to serve patients.

Based from fact was described on previous paragraph, much data on Operational System and MIS can be explored or exploited by BI application into useful information and knowledge for a health center. With this information and knowledge, a health center can optimize the operational by: (1) Allocating logistic and supply with better performance, because with the BI application, health center can seen when the drug or medical equipment needed. (2) Better diagnosing a disease, because from digital medical record, BI application can found pattern, when an illness become worst disease, with seen on certain time of medical records. (3) Giving better treatment to curing the disease, with seen on what treatment effectively to curing a sickness. (4) Determining the drug which effective curing a disease. (5) Predicting an epidemics on certain area with view the tendency of the inpatient or outpatient at any given time. (6) Allocating or scheduling employees, nurses and doctors better, with a tendency to see patterns of patients coming for treatment.

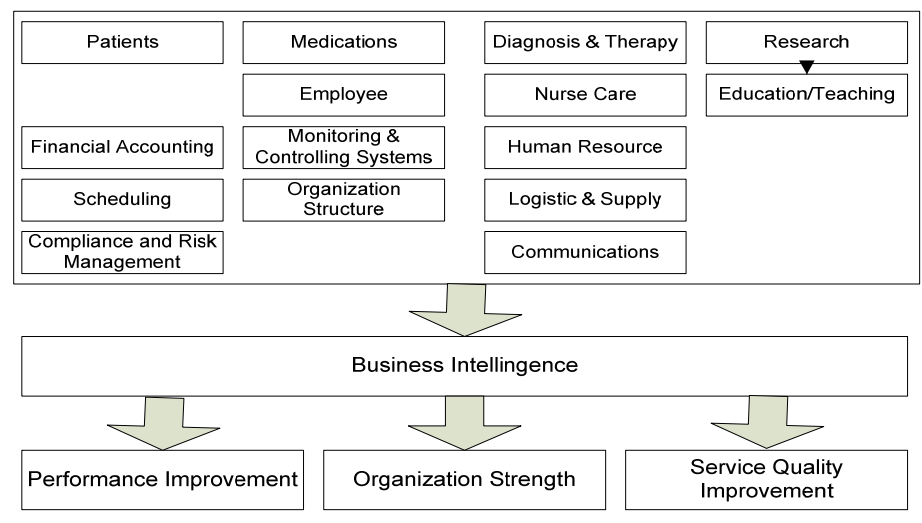

Figure 1 Business Intelligence Opportunity

Finally with information and knowledge from BI, the performance of a health center can be optimized and improved. It will strengthen the organization on financial for the efficient and effective operation and give better service to community. This article only explores the possibility of developing Intelligent Business applications from board point of view. For the next, on subsequent research, it will analyze a system operating of a health center, create a data warehouse; perform data mining and present strategic information for a health center. 


\section{CONCLUSION}

A Business Intelligence application can be applied to a health center. The level of implementation of BI application depends on the readiness of the health center and number of computerized operational systems that will provide greater opportunity for the implementation of BI applications. However, it also depends on of how the data maturity of the operational system designed and built. By applying Business Intelligence applications on a Health Center, information from the operational data can be maximized. With this good information, decision making on health center can be more strategic. Health centers that have enough strategic information from inside or outside the organization, will have high competitiveness exceed health centers that do not have it. Application of Business Intelligence applications can be performed on all sectors, the quality of the information depends on the quality of data and how the data mining process is done. However, poor quality of strategic decisions relies on the quality of the decision-makers. It is time for businesses using Business Intelligence for competitive advantages.

\section{REFERENCES}

A, T., Stegwee, R. A., \& Teitink, C. J. (2002). Business Inteligent in Healthcare Organisazation. Proceeding of the 35th Hawaii International Conference on System Sciences .

Ashrafi, N., Kelleher, L., Kuilboer, J.-P. (2014). The Impact of Business Intelligence on Healthcare Delivery in the USA. Interdisciplinary Journal of Information, Knowledge, and Management, 9: $117-130$.

Hanson, R. (2011). Good Health Information-An Asset not a burden!, 35, Australian Health Review.

Inmon, W. H. (2005). Building the Data Warehouse (Fourth ed.). Wiley Publishing, Inc.

Mettler, T., Vimarlund, V. (2009). Understanding Business Intelligence in the Context of Health Care. Tobias Mettler , 15: 254-264.

Nelson, M. L., \& Sen, R. (2014). Business rules management in healthcare: A lifecycle approach, 57, Decision Support Systems.

Ponniah, P. (2010). Data warehousing fundamentals for IT professionals (2nd ed ed.). John Wiley \& Sons, Inc.

Sabherwal, R., \& Becerra Fernandez, I. (2011). Business intelligence practices technologies, and management. Hoboken, NJ: John Wiley \& Sons.

Vercellis, C. (2009). Business Intelligence: Data Mining and Optimization for Decision Making. John Wiley \& Sons, Ltd.

Williams, S., \& Williams, N. (2007). The Profit Impact of Business Intelligence. Morgan Kaufmann Publishers. 